\title{
Aspects of pre-eclamptic toxaemia of pregnancy, consanguinity, and twinning in Ankara
}

\author{
ALAN C. STEVENSON,* BURHAN SAY, $†$ SEDAT USTAOGLU, $\ddagger$ and \\ ZIYA DURMUS $\ddagger$
}

Summary. It appears that women classed as having pre-eclamptic toxaemia are less frequently consanguineous with their husbands than all other mothers and in particular those mothers classed as having pregnancies complicated by chronic hypertensive disease. Search revealed no evidence for possible biases which could have simulated such findings.

Further evidence is advanced suggesting that, though pre-eclamptic toxaemia is more common in all types of twin pregnancies than in single births, it is more common where the twins are dizygous than where they are monozygous.

It is pointed out that both these findings would be expected if there was a contribution to the aetiology of pre-eclamptic toxaemia by maternal/fetal immunological incompatibility. However, if such a mechanism exists it is not always determined at the same gene locus.

Starting in 1971 a special study was made of all women delivered in the Dogum Evi Hospital, Ankara. From data accumulated after the first 5286 mothers who had been delivered, Stevenson et al (1971) concluded that the proportion of women who had pre-eclamptic toxaemia who were related to their husbands was significantly less than in the other patients.

By early 1973, 23416 mothers with single pregnancies and 271 with twin pregnancies had been studied. Basic information concerning these patients is set out in Table I. Records in respect of 58 of the patients with single pregnancies were incomplete in respect of one or more of the variables presented in subsequent tables, so these forms were ignored and the total in subsequent tables is 23358 . Ten women (none classified as having pre-eclamptic toxaemia) were identified as having been admitted for two pregnancies during the period of the study. The data from both admissions have been included.

Received 16 December 1974.

* MRC Population Genetics Unit, Old Road, Headington, Oxford. Present address: Southern District-Highland Health Board, Old Laboratories, Royal Northern Infirmary, Inverness IV3 5SF.

+ Department of Paediatrics, the Hacettepe University, Ankara, Turkey.

¥ Doğum Evi Hospital, Ankara, Turkey.
TABLE I

OUTLINE OF DATA

\begin{tabular}{|c|c|c|}
\hline Single births & $\begin{array}{l}\text { Males } \\
\text { Females } \\
\text { Total (births) }\end{array}$ & $\begin{array}{l}12455 \\
10961 \\
23416\end{array}$ \\
\hline Twin births & $\begin{array}{l}\text { MM pairs } \\
\text { MF pairs } \\
\text { FF pairs } \\
\text { Total (pregnancies) } \\
\text { Total (births) }\end{array}$ & $\begin{array}{r}80 \\
112 \\
79 \\
271 \\
542\end{array}$ \\
\hline $\begin{array}{l}\text { Grand total (pregnancies) } \\
\text { Grand total (births) }\end{array}$ & & $\begin{array}{l}23687 \\
23958\end{array}$ \\
\hline \multicolumn{3}{|c|}{$\begin{array}{l}\text { Frequency of 'true' pre-eclamptic toxaemia per } 1000 \text { total } \\
\text { births }\end{array}$} \\
\hline \multicolumn{2}{|c|}{$\begin{array}{l}\text { Stillbirth rate per } 1000 \text { total births } \\
\text { Live births - died before leaving hospital per } 1000 \text { total } \\
\text { births } \\
\text { 'Perinatal' mortality per } 1000 \text { total births }\end{array}$} & $\begin{array}{l}17.0 \\
36.3\end{array}$ \\
\hline
\end{tabular}

Proportion of mothers in relationship with their husbands:

Coefficient of inbreeding* $\frac{1}{16}$ (first cousins) $\quad 13.4 \%$ $\frac{1}{32}$ (fïst cousins one removed) $\quad 2.8 \%$ $\frac{1}{64}$ or less (second cousins or less) $0.8 \%$ Any consanguinity

$17.0 \%$

* These coefficients are really those of the offspring of such marriages, but as a convenience (with many precedents!) they are applied in this and other Tables to the marriages. 


\section{Methods}

Conduct of study. Forms for recording relevant information about patients were bound together in packs of 100. Each pack also had a set of directions for completion of the forms, and a copy of the classification of preeclamptic toxaemia (PET) and hypertensive disorders complicating pregnancy, which was that of the American Committee on Maternal Welfare (Hellman and Pritchard, 1971). This classification is, for convenience, reproduced in the Appendix.

Recording of consanguinity. Patients were seen as soon after admission as possible by one of the two social workers and questioned about any relationship with their husbands. If the patient's husband was her first cousin, one of the diagrammatic pedigrees showing the four possible types of first cousin (see Table VIII) was ticked. If there was a relationship, but it was other than that of first cousin, a diagrammatic pedigree was drawn. Coefficients of inbreeding were subsequently added to the records.

For simplicity a single instance of coefficient of inbreeding of $1 / 8$ was classed as $1 / 16$, and two of $1 / 128$ as $1 / 64$. The recording of consanguinity and that of data relevant to PET and its assessment were done independently by different individuals.

In Turkish families, consanguineous marriages are much favoured and relationships of spouses are very important, so that they are well known to, and understood by, spouses. There is little doubt, however, that some marriages classed as non-consanguineous were really between distant relatives.

Recording of toxaemia. The basic data were recorded by the obstetrician in charge of the patient, and the assessment, according to the classification used, was decided upon after discussion with a senior staff member.

The many difficult problems of distinguishing between true PET (however defined and if such an entity exists!) were further complicated in the Doğum Evi
Hospital by the fact that only about $10 \%$ of patients were seen at antenatal clinics before the 24th week of pregnancy so that, for most patients, the vital criterion that the blood pressure rose only after the 24th week could not be established. This matter is considered below in comparisons of times when patients with and without PET were first seen (see Table IV). Blood pressures of all patients were taken before discharge from hospital.

\section{Results}

Maternal age and parity and frequency of PET by parity. From Table II it will be seen that the mean frequency of pre-eclamptic toxaemia in single pregnancies was $2.4 \%$. A surprisingly high proportion of all women in Ankara are confined in hospital, probably over $95 \%$, and the Dogum Evi, being a large public hospital, admits all who apply. The problems of comparing the frequencies of PET in patients in different hospitals with different admission priorities are well discussed by Davies (1971).

Also from Table II it will be seen that the frequency of PET is relatively high in first pregnancies, falling in subsequent pregnancies, but rising again from fifth pregnancies onwards. This is a very similar pattern to that in the Shatby Hospital, Alexandria (Einen and Toppozada, 1966) and in Jerusalem (Davies et al, 1970; Davies, 1971), though the frequencies in both the Doğum Evi and the Shatby Hospitals rise to even higher levels than in Jerusalem in pregnancy orders eight and above.

The data on maternal age and parity in Table II probably give a picture only approximating to the truth, as patients are often uncertain as to their ages, and multipara may not accurately remember previous mature births. Data on abortions in past pregnancies were recorded but showed so many

TABLE II

SINGLE BIRTHS: MATERNAL AGES, MATURE BIRTH ORDERS AND FREQUENCY OF TOXAEMIA BY BIRTH ORDERS

\begin{tabular}{|c|c|c|c|c|c|c|c|c|c|c|}
\hline \multirow{2}{*}{$\begin{array}{l}\text { Mature Birth } \\
\text { Order* }\end{array}$} & \multicolumn{8}{|c|}{ Maternal Age } & \multicolumn{2}{|c|}{$\begin{array}{l}\text { True Toxaemia in this } \\
\text { Pregnancy }\end{array}$} \\
\hline & $0-19$ & $20-24$ & $25-29$ & $30-34$ & $35-39$ & $40-44$ & $45+$ & Total & No. & $\underset{(\%)}{\text { Frequency }}$ \\
\hline $\begin{array}{c}1 \\
2 \\
3 \\
4 \\
5 \\
6 \\
7 \\
8 \\
9 \\
10+\end{array}$ & $\begin{array}{r}1557 \\
2149 \\
454 \\
123 \\
19 \\
11 \\
1 \\
1 \\
0 \\
0\end{array}$ & $\begin{array}{r}1878 \\
3762 \\
2177 \\
1009 \\
333 \\
174 \\
6 \\
1 \\
0 \\
0\end{array}$ & $\begin{array}{r}522 \\
1308 \\
1259 \\
1011 \\
637 \\
359 \\
9 \\
8 \\
1 \\
0\end{array}$ & $\begin{array}{r}146 \\
296 \\
393 \\
472 \\
513 \\
372 \\
229 \\
157 \\
27 \\
7\end{array}$ & $\begin{array}{r}35 \\
101 \\
132 \\
168 \\
242 \\
209 \\
179 \\
143 \\
94 \\
261\end{array}$ & $\begin{array}{l}10 \\
21 \\
15 \\
21 \\
38 \\
39 \\
50 \\
41 \\
27 \\
91\end{array}$ & $\begin{array}{r}0 \\
6 \\
5 \\
7 \\
6 \\
9 \\
4 \\
4 \\
1 \\
18\end{array}$ & $\begin{array}{r}4148 \\
7643 \\
4435 \\
2811 \\
1788 \\
1173 \\
478 \\
355 \\
150 \\
377\end{array}$ & $\begin{array}{r}112 \\
135 \\
69 \\
51 \\
58 \\
45 \\
23 \\
14 \\
9 \\
38\end{array}$ & $\begin{array}{r}2.70 \\
1.77 \\
1.55 \\
1.81 \\
3.24 \\
3.83 \\
4.81 \\
3.94 \\
6.00 \\
10.08\end{array}$ \\
\hline Total & 4315 & 9340 & 5114 & 2612 & 1564 & 353 & 60 & 23358 & 554 & 2.37 \\
\hline
\end{tabular}

* Birth order ignoring pre-28th week miscarriages. 
discrepancies as to be worthless. The first column in Table II suggests that a few women have a remarkable number of children before the age of 20 years. The data may not be accurate, but it has to be remembered that in country districts a girl may be married at 12 to 14 years, and Ankara is a magnet for poor labourers from a huge hinterland.

Consanguinity of patients and PET. Table III sets out the numbers of patients with single pregnancies in respect of PET, hypertensive disease complicating pregnancy, and degrees of relationship, if any, to their husbands.

It will be seen that the frequency of any recorded degrees of consanguinity in mothers with PET $\left(\mathrm{IA}_{1}, \mathrm{IA}_{2}\right.$, or IB) is $63 / 554$. This is significantly less than the frequency in mothers who had no hypertension or PET (group IV) which was 3873/ $22573\left(\chi^{2}=12.4108, \quad \mathrm{df}=1, \quad \mathrm{P}<0.001\right)$. Consanguinity is also significantly less in mothers with PET than in those judged to have had hypertensive disease complicating pregnancy $\left(\right.$ IIA $_{1}$, IIA $_{2}$, IIB) which was $37 / 188\left(\chi^{2}=7.6133, \mathrm{df}=1, \mathrm{P}<0.01\right)$.

However, there is no significant difference in the frequency of consanguinity between women who had hypertensive disease (37/188) and those who had neither hypertensive disease nor PET (group IV) $(3873 / 22573)\left(\chi^{2}=0.6663, \mathrm{df}=1,0.3<\mathrm{P}<0.5\right)$.

In view of this apparent overall effect of consanguinity, it might be expected that there would be a negative correlation between coefficients of inbreeding and frequency of PET. The frequency of PET in women where the coefficients of inbreeding were $1 / 16,1 / 32$, and $1 / 64$, were, respectively $50 / 3135$ $(1.59 \%), 9 / 669(1.34 \%)$, and $4 / 178(2.24 \%)$. Unfortunately the numbers in the classes of mothers with the two lower coefficients of inbreeding are too small to enable any conclusions to be drawn.

In considering Table III the few patients classed as having 'unclassifiable' toxaemia (group III) have been ignored. The classification is vague, and the number very small, so that however they are apportioned to classes I or II would not affect the significance of comparisons.

These data appear to support the suspicions raised by the data from Shatby Hospital, Alexandria (Einen and Toppozada, 1966; Stevenson et al, 1971) that consanguinity is less frequent in women whose pregnancies were complicated by PET than in other mothers.

There are two possible biases which might effect the data assembled: (1) mothers who subsequently developed PET might, on average, attend antenatal clinics only later in pregnancy than other mothers; (2) consanguinity rates may be falling so rapidly in the growing city of Ankara that it would be expected to be less frequent in younger mothers and in those of low parity than in older multiparous women. Further, it is these younger women who account for most cases of PET.

Table IV does not suggest that bias arises from differences in proportions of mothers first seen in varying stages of pregnancy. Evidence for the second possible source of bias is not apparent from the data in Tables V and VI. There is no evidence of significant differences in frequency of consanguinity in younger compared with older mothers, or those in early birth orders compared with later birth orders.

Another possible source of bias would be if both PET and consanguinity were more common in mothers from poorer homes than in those more

TABLE III

SINGLE PREGNANCIES: TOXAEMIA OF PREGNANCY, HYPERTENSIVE DISEASE OR NEITHER, AND CONSANGUINITY OF MOTHERS AND THEIR HUSBANDS

\begin{tabular}{|c|c|c|c|c|c|c|}
\hline \multirow{2}{*}{$\begin{array}{c}\text { Classification of Mothers by } \\
\text { Presence or Absence of } \\
\text { Toxaemia or Chronic Hypertensive } \\
\text { Disease* }\end{array}$} & \multicolumn{4}{|c|}{$\begin{array}{l}\text { Relationships of Mothers and their Husbands } \\
\text { (coefficient of inbreeding) }\end{array}$} & \multicolumn{2}{|c|}{ Totals } \\
\hline & $1 / 16$ & $1 / 32$ & $1 / 64$ & Zero & No. & $\begin{array}{c}\text { Consanguinity } \\
(\%)\end{array}$ \\
\hline $\begin{array}{l}\text { Group I: Pre-eclamptic toxaemia } \\
\text { IA }_{1} \text { (mild) } \\
\text { IA }_{2} \text { (severe) } \\
\text { IB (eclampsia) } \\
\text { Total toxaemia } \\
\text { Group II: Hypertensive disease } \\
\text { IIA : Known before pregnancy } \\
\text { IIA : Discovered during pregnancy } \\
\text { IIB: With superimposed toxaemia } \\
\text { Total hypertensive disease } \\
\text { Group III: Unclassifiable 'toxaemia' } \\
\text { Group IV: No hypertension or toxaemia } \\
\text { All mothers }\end{array}$ & $\begin{array}{r}38 \\
8 \\
4 \\
50 \\
\\
3 \\
26 \\
0 \\
29 \\
7 \\
3049 \\
3135\end{array}$ & $\begin{array}{r}9 \\
0 \\
0 \\
9 \\
0 \\
0 \\
4 \\
0 \\
4 \\
2 \\
654 \\
669\end{array}$ & $\begin{array}{r}1 \\
1 \\
2 \\
4 \\
\\
1 \\
3 \\
0 \\
4 \\
0 \\
170 \\
178\end{array}$ & $\begin{array}{r}364 \\
100 \\
27 \\
491 \\
\\
16 \\
135 \\
0 \\
151 \\
34 \\
18700 \\
19376\end{array}$ & $\begin{array}{r}412 \\
109 \\
33 \\
554 \\
\\
20 \\
168 \\
0 \\
188 \\
43 \\
22573 \\
23358\end{array}$ & $\begin{array}{r}11.65 \\
8.25 \\
18.18 \\
11.37 \\
20.00 \\
19.64 \\
19.68 \\
20.93 \\
17.16 \\
17.05\end{array}$ \\
\hline
\end{tabular}

* For classification see Appendix. 
TABLE IV

SINGLE PREGNANCIES: TIMES WHEN FIRST SEEN IN PREGNANCY IN WOMEN WHO DID OR DID NOT HAVE PRE-ECLAMPTIC TOXAEMIA

\begin{tabular}{|c|c|c|c|}
\hline \multirow[b]{2}{*}{$\begin{array}{l}\text { Weeks when } \\
\text { First Seen }\end{array}$} & \multicolumn{3}{|c|}{ Pregnancy } \\
\hline & $\begin{array}{c}\text { Pre-eclamptic } \\
\text { Toxaemia } \\
\left(\mathbf{I} \mathbf{A}_{\mathbf{1}}, \mathbf{I A}_{\mathbf{2}} \text {, and IB }\right)\end{array}$ & $\begin{array}{c}\text { No Pre-eclamptic } \\
\text { Toxaemia } \\
\text { (II, III, and IV) }\end{array}$ & Total \\
\hline $\begin{array}{r}0-11 \\
12-17 \\
18-23 \\
24-29 \\
30-35 \\
36+\end{array}$ & $\left.\begin{array}{r}25 \\
24 \\
13 \\
25 \\
14 \\
453\end{array}\right\} 11.2 \%$ & $\begin{array}{r}1051 \\
961 \\
383 \\
1191 \\
525 \\
18693 \\
\end{array}$ & $\begin{array}{r}1076 \\
985 \\
396 \\
1216 \\
539 \\
19146\end{array} 10.5 \%$ \\
\hline Total & 554 & 22804 & 23358 \\
\hline
\end{tabular}

favoured socially and economically. After much discussion it was decided not to attempt to ask questions of mothers which might have permitted some socioeconomic groupings. In a trial before recording began it was found that many women said they did not know their husbands' occupations, and other questions about income aroused resentment and suspicion. Patients admitted to the hospitals are predominantly from low income households, the majority of husbands being casual workers, or at least not members of any social security scheme. Others were small street traders. Very few were artisans or could be classed as skilled or semiskilled workers.

TABLE V

SINGLE BIRTHS: PRE-ECLAMPTIC TOXAEMIA IN WOMEN CONSANGUINEOUS AND NOT CONSANGUINEOUS WITH THEIR HUSBANDS, RELATED TO MATERNAL AGE

\begin{tabular}{|c|c|c|c|c|c|c|c|c|c|}
\hline \multirow{3}{*}{$\begin{array}{l}\text { Classification } \\
\text { of Toxaemia }\end{array}$} & \multicolumn{9}{|c|}{ Maternal Age } \\
\hline & \multicolumn{3}{|c|}{$0-24$} & \multicolumn{3}{|c|}{$25+$} & \multicolumn{3}{|c|}{ Total } \\
\hline & $\begin{array}{c}\text { Con- } \\
\text { sanguinity }\end{array}$ & $\begin{array}{l}\text { No Con- } \\
\text { sanguinity }\end{array}$ & Total & $\begin{array}{c}\text { Con- } \\
\text { sanguinity }\end{array}$ & $\begin{array}{l}\text { No Con- } \\
\text { sanguinity }\end{array}$ & Total & $\begin{array}{c}\text { Con- } \\
\text { sanguinity }\end{array}$ & $\begin{array}{l}\text { No Con- } \\
\text { sanguinity }\end{array}$ & Total \\
\hline PET (I) & \multirow{3}{*}{$\begin{array}{c}35 \\
(10.90 \%) \\
2266 \\
(17.0 \%) \\
2301 \\
(16.8 \%)\end{array}$} & 286 & 321 & \multirow{3}{*}{$\begin{array}{c}28 \\
(12.0 \%) \\
1653 \\
(17.5 \%) \\
1681 \\
(17.3 \%)\end{array}$} & 205 & 233 & \multirow{3}{*}{$\begin{array}{c}63 \\
(11.4 \%) \\
3919) \\
(172 \%) \\
3982 \\
(17.0 \%)\end{array}$} & 491 & 554 \\
\hline $\begin{array}{l}\text { NoPET } \\
\text { (II,III, and IV) }\end{array}$ & & 11068 & 13334 & & 7817 & 9470 & & 18885 & 22804 \\
\hline Total & & 11354 & 13655 & & 8022 & 9703 & & 19376 & 23358 \\
\hline
\end{tabular}

* See Appendix.

TABLE VI

SINGLE BIRTHS: PRE-ECLAMPTIC TOXAEMIA IN WOMEN CONSANGUINEOUS AND NOT CONSANGUINEOUS WITH THEIR HUSBANDS, RELATED TO BIRTH ORDER

\begin{tabular}{|c|c|c|c|c|c|c|c|c|c|}
\hline \multirow{3}{*}{$\begin{array}{l}\text { Classification } \\
\text { of Toxaemia }\end{array}$} & \multicolumn{6}{|c|}{ Birth Order } & & & \\
\hline & \multicolumn{3}{|c|}{$1-4$} & \multicolumn{3}{|c|}{$5+$} & \multicolumn{3}{|c|}{ All } \\
\hline & $\begin{array}{c}\text { Con- } \\
\text { sanguinity }\end{array}$ & $\begin{array}{l}\text { No Con- } \\
\text { sanguinity }\end{array}$ & Total & $\begin{array}{c}\text { Con- } \\
\text { sanguinity }\end{array}$ & $\begin{array}{l}\text { No Con- } \\
\text { sanguinity }\end{array}$ & Total & $\begin{array}{c}\text { Con- } \\
\text { sanguinity }\end{array}$ & $\begin{array}{l}\text { No Con- } \\
\text { sanguinity }\end{array}$ & Total \\
\hline PET (I) & $\begin{array}{c}44 \\
(12.0 \%)\end{array}$ & 323 & 367 & $\begin{array}{c}19 \\
(10.2 \%)\end{array}$ & 168 & 187 & $\begin{array}{c}63 \\
4 \%\end{array}$ & 491 & 554 \\
\hline $\begin{array}{l}\text { No PET } \\
\text { II, III and IV }\end{array}$ & $\begin{array}{l}3174 \\
(17.0 \%)\end{array}$ & 15496 & 18670 & $\begin{array}{l}745 \\
(17.3 \%)\end{array}$ & 3389 & 4134 & 3919 & 18885 & 22804 \\
\hline All & $\begin{array}{c}3218 \\
(16.9 \%)\end{array}$ & 15819 & 19037 & $\begin{array}{c}764 \\
(17.6 \%)\end{array}$ & 3557 & 4321 & $\begin{array}{l}3982 \\
(17.05 \%)\end{array}$ & 19376 & 23358 \\
\hline
\end{tabular}

TABLE VII

SINGLE PREGNANCIES-TOXAEMIA OF PREGNANCY AND HYPERTENSION BY TYPE OF FIRST-COUSIN MARRIAGE

\begin{tabular}{|c|c|c|c|c|c|}
\hline \multirow{2}{*}{ Type } & \multicolumn{4}{|c|}{ First Cousin Type* } & \multirow{2}{*}{ Total } \\
\hline & 1 & 2 & 3 & 4 & \\
\hline $\begin{array}{l}\text { True toxaemia } \\
\text { Hypertension (or unclassifiable) } \\
\text { Neither } \\
\text { Total }\end{array}$ & $\begin{array}{r}16 \\
12 \\
1007 \\
1035\end{array}$ & $\begin{array}{r}10 \\
8 \\
671 \\
689\end{array}$ & $\begin{array}{r}10 \\
7 \\
640 \\
657\end{array}$ & $\begin{array}{r}14 \\
9 \\
731 \\
754\end{array}$ & $\begin{array}{r}50 \\
36 \\
3049 \\
3135\end{array}$ \\
\hline Frequency of true toxaemia & $1.54 \%$ & $1.45 \%$ & $1.53 \%$ & $1.86 \%$ & $1.59 \%$ \\
\hline
\end{tabular}

- See Table VIII. 
Types of first-cousin marriages and PET. Table VII sets out the data for first-cousin marriages broken down by type on PET. There is no suggestion that any one type of first-cousin marriage is more relevant to PET than another.

Types of first-cousin marriages in Alexandria and Ankara. In Alexandria the frequency

TABLE VIII

SINGLE BIRTHS: TYPES OF FIRST-COUSIN MARRIAGES, ANKARA AND ALEXANDRIA

\begin{tabular}{l|c|c}
\hline \multirow{2}{*}{ Types of First-cousin Marriage } & $\begin{array}{c}\text { Numbers and Proportions } \\
\text { of each Type }\end{array}$ \\
\cline { 2 - 3 } & Ankara & Alexandria \\
\hline 1. Spouses were offspring of two & 1035 & 506 \\
brothers & $(33.0 \%)$ & $(27 \%)$ \\
2. Spouses were offspring of two & 689 & 415 \\
sisters & $(22.0 \%)$ & $(22 \%)$ \\
3. Woman was married to son of her & 657 & 566 \\
mother's brother & $(21.0 \%)$ & $(30 \%)$ \\
4. Woman was married to son of her & 754 & 405 \\
father's sister & $(24.0 \%)$ & $(21 \%)$ \\
Total first-cousin marriages & 3135 & 1892 \\
\hline
\end{tabular}

of first-cousin marriages in 9586 mothers was $22.0 \%$, which is higher than in Ankara (13.4\%). However the distribution of the types of first-cousin marriages was very different in the two hospitals as can be seen from Table VIII.

In Ankara about one-third of all first-cousin marriages are of type 1 , between the children of two brothers. However, in Alexandria the most frequent type is 3 , where a man marries his father's sister's daughter.

It is interesting to note that in neither country, at least among professional people, does there seem to be any recognition of these preferences. When pointed out no consistent explanations are offered in either country. (The problem is of interest to the social anthropologist.)

PET and twin pregnancies. In the preliminary paper (Stevenson et al, 1971), analysis of twin data available from Alexandria, the British National Birthday Trust, Belfast, and Oxford showed that PET was consistently lower in mothers

TABLE IX

FREQUENCIES OF PET IN PREGNANCIES BY TWIN TYPES

\begin{tabular}{|c|c|c|c|c|c|c|c|c|}
\hline \multirow{3}{*}{ Centre } & \multirow{2}{*}{\multicolumn{2}{|c|}{$\begin{array}{l}\text { Like Sexed } \\
\text { Pairs }\end{array}$}} & \multirow{2}{*}{\multicolumn{2}{|c|}{$\begin{array}{l}\text { Unliked Sexed } \\
\text { Pairs }\end{array}$}} & \multicolumn{4}{|c|}{ Estimated } \\
\hline & & & & & \multicolumn{2}{|c|}{ Monozygous Pairs } & \multicolumn{2}{|c|}{ Dizygous Pairs } \\
\hline & All & PET & All & PET & All & PET & All & PET \\
\hline Alexandria & 204 & 24 & 143 & 21 & 61 & 3 & 286 & 42 \\
\hline UK (National Birthday & 142 & $54 \%$ & 54 & $\begin{array}{l}(14.7 \%) \\
28\end{array}$ & 88 & $26 \%$ & 108 & 56 \\
\hline Belfast & 337 & & 208 & & 129 & & 416 & $(51.9 \%)$ \\
\hline Oxford & 314 & $(17.5 \%)$ & 185 & $(25.5 \%)$ & 129 & $(4.6 \%)$ & 370 & $(25.5 \%)$ \\
\hline Ankara & 159 & $\begin{array}{c}(40.8 \%) \\
14 \% \\
(8.80 \%)\end{array}$ & 112 & $\begin{array}{c}(50.3 \%) \\
13 \\
(11.6 \%)\end{array}$ & 47 & $\begin{array}{c}(27.2 \%) \\
1 \%) \\
(2.1 \%)\end{array}$ & 224 & $\begin{array}{c}(50.3 \%) \\
26 \% \\
(11.6 \%)\end{array}$ \\
\hline
\end{tabular}

TABLE X

SINGLE BIRTHS: CONSANGUINITY AND PERINATAL DEATHS

\begin{tabular}{|c|c|c|c|c|c|c|c|c|c|}
\hline \multirow{2}{*}{$\begin{array}{l}\text { Coefficient } \\
\text { of } \\
\text { Inbreeding }\end{array}$} & \multicolumn{7}{|c|}{ Outcome of Pregnancy } & \multicolumn{2}{|c|}{ Per 1000 Total Births } \\
\hline & MLB & FLB & $\begin{array}{c}\text { MLB } \\
\text { (D) }\end{array}$ & $\begin{array}{c}\text { FLB } \\
\text { (D) }\end{array}$ & MSB & FSB & Total & $\begin{array}{c}\text { Stillbirth } \\
\text { Rate }\end{array}$ & $\begin{array}{l}\text { 'Perinatal' } \\
\text { Mortality }\end{array}$ \\
\hline $\begin{array}{r}1 / 16: \text { type } 1 \\
\text { type } 2 \\
\text { type } 3 \\
\text { type } 4 \\
\text { total }\end{array}$ & $\begin{array}{r}557 \\
322 \\
331 \\
373 \\
1583 \\
\end{array}$ & $\begin{array}{r}437 \\
329 \\
299 \\
356 \\
1421 \\
\end{array}$ & $\begin{array}{r}9 \\
6 \\
9 \\
7 \\
31\end{array}$ & $\begin{array}{r}11 \\
7 \\
4 \\
2 \\
24\end{array}$ & $\begin{array}{r}12 \\
11 \\
7 \\
8 \\
38\end{array}$ & $\begin{array}{r}9 \\
14 \\
7 \\
8 \\
38\end{array}$ & $\begin{array}{r}1035 \\
689 \\
657 \\
754 \\
3135\end{array}$ & $\begin{array}{l}20.3 \\
36.3 \\
21.3 \\
21.2 \\
24.2\end{array}$ & $\begin{array}{l}39.6 \\
57.8 \\
41.1 \\
33.2 \\
41.8\end{array}$ \\
\hline $1 / 32$ & 316 & 322 & 9 & 6 & 11 & 5 & 669 & 23.9 & 46.3 \\
\hline $1 / 64$ & 97 & 70 & 2 & 4 & 2 & 3 & 178 & 28.1 & 61.8 \\
\hline All consanguineous & 1996 & 1813 & 42 & 34 & 51 & 46 & 3982 & 24.4 & 43.4 \\
\hline Zero & 9851 & 8849 & 175 & 148 & 178 & 175 & 19376 & 18.2 & 34.9 \\
\hline Total births & 11847 & 10662 & 217 & 182 & 229 & 221 & 23358 & 19.3 & 36.3 \\
\hline
\end{tabular}


with pregnancies of like sexed than in those with unlike sexed twins and that estimates suggested highly significantly higher rates in mothers with dizygous than with monozygous twins. When this paper was published there were insufficient data to analyse from Ankara, but information on 271 pairs has now accumulated, and as can be seen from Table IX, shows the same order of magnitude of higher frequency of toxaemia in mothers with unlike sex twin pregnancies as in the other studies. However, the numbers from Ankara are small and the estimated difference between monozygous and dizygous twins is not technically significant, $\chi^{2}=$ 2.9066 (Yates correction) $\mathrm{P}<0.1$. Nevertheless, the consistency of the five sets of data on toxaemia in twin pregnancies is very impressive.

Consanguinity and perinatal death. It has been reported from time to time that stillbirth rates and perinatal mortality are higher in the progeny of related than of unrelated parents (Stevenson $e t$ al, 1966). The relevant data from this study are set out in Table X. It will be seen that the 'perinatal' mortality in offspring of mothers in any way related to their husbands (173/3982) is significantly higher than in those of unrelated mothers (676/19 376): $\chi^{2}=6.6630, \mathrm{df}=1, \mathrm{P}<0.01$. 'Perinatal' mortality is used in the loose sense of stillbirths plus deaths of infants in hospital per 1000 total births.

\section{Discussion}

It is not intended to discuss the numerous hypotheses as to the aetiology of toxaemia. Excellent reviews are those of Jeffcoate (1966) and of Davies (1971) who both quote Zweifel's dictum (1895) that pre-eclamptic toxaemia is the 'disease of theories'.

It has often been suggested that a factor in the aetiology could be a maternal/fetal incompatibility and in the most general terms it is clearly more likely that women and their husbands who are consanguineous will on average have more identical ancestral genes in common than will spouses who are not related. A conceptus of such a marriage would in turn be less likely to have genes not possessed by their mothers and possibly producing foreign antigens. Studies of consanguinity and PET are not practicable unless, in the population sampled, the consanguinity rate is relatively high. For example, in the United Kingdom, where the frequency of consanguineous marriages is perhaps about $1 / 300$, and of PET perhaps $3 / 100$, the random chance of PET in a consanguineous marriage is $3 / 20000$, so that studies would be impossibly laborious if sufficient data were to be obtained. On the other hand consanguinity is now only high in certain relatively underdeveloped countries. It is, therefore, difficult to find places in which there exist the necessary conditions for a study which can be undertaken successfully in a few years. These conditions are: hospitals where the clinical standards are high, where there are a large number of births each year, and where the frequency of consanguineous marriages is high. In the Doğum Evi Hospital all three conditions are satisfied (the responsibility for suggesting the first is that of A.C.S.)!

The biggest problem in all studies of PET is in distinguishing between PET however defined, and a manifestation during pregnancy of pre-existing essential hypertension or chronic kidney disease. In this study the fact that so few patients were seen before 29 weeks makes the problem even more difficult.

However, at least approximately the same proportions of women who do and who do not develop PET are seen before 24 weeks (Table IV).

The data in Table III seem to suggest strongly that consanguinity is less frequent in women classed as having PET than in others. It is interesting to note that the criterion of consanguinity identifies as different those women classed as having PET (group I) and those classed as having chronic hypertensive disease (group II).

Browne and Sheumack (1956) produced evidence that hypertensive disease was more common in close relatives of patients regarded as having PET than in others. However, chronic hypertensive disease would be unlikely to be more common in women who contracted consanguineous marriages. The genetic contribution to familial hypertensive disease is probably multigenic (Hamilton et al, 1954) and might, under certain circumstances, be more common in women whose parents were consanguineous.

As discussed in the earlier paper, two 'models' of maternal/fetal incompatibility based on a single gene locus as a possible explanation of PET have been advanced and considered in association with data on familial occurrence of PET. If the alternative alleles are $T$ and $t$, then on the first model the prerequisites for incompatibility are $T t$ fetus in a tt mother (i.e., a rhesus-like situation), and the second a tt fetus in a $\mathrm{Tt}$ mother. It is easy to produce elaborate expressions based on either of these models for prediction of frequencies in specified relatives in women related to their husbands, and in monozygous and dizygous twin pregnancies, assuming various gene frequencies. However, both these hypotheses involving a single locus are incompatible with the 
phenomenon of a woman having a pregnancy complicated by PET which results in a daughter who, in turn has a pregnancy complicated by PET. Yet there can be no doubt that this occurs (Humphries, 1960; Chesley, Annitto, and Cosgrove, 1968). However, PET in a daughter born from a PET-complicated pregnancy of her mother is perfectly compatible with series of alleles at different loci each capable of determining the incompatibilities in mother and daughter.

The data on twin pregnancies are also explicable on a maternal/fetal incompatibility hypothesis whether determined at one or several gene loci. As is clear from Table IX, PET frequencies in pregnancies with like sexed twins are lower than in those with twins of unlike sex, but the differences are of borderline significance. However, when estimates were made from the data of the frequencies in monozygous and in dizygous twins, though these estimates were not necessarily very accurate, the significances of the differences are impressive; even if the higher frequency of PET in the presumptive dizygous twin pregnancies is not technically significant in the present data.

It seems, therefore, that the evidence in accord with a hypothesis of fetal incompatibility contribution to PET is impressive both from study of consanguineous marriages and twin pregnancies. That is not to say that if there is such a contribution it is the only factor, or even the factor which contributes most to the frequency of PET. It could, however, be the sine qua non of the occurrence of PET with endocrine, nutritional, and other less clearly identified factors determining sufficient disturbance in many patients for the clinical signs to reach the, of necessity, arbitrary criteria which are accepted for a clinical diagnosis.

There are two conclusions which seem important to the authors: (1) within a few years there will be few communities in the world where consanguinity rates will be sufficiently high for our findings to be confirmed in another population. It is to be hoped that appropriate work will be done. (2) The authors do not feel competent to discuss work which has been done on immunological responses by mothers to genetically 'foreign' fetuses, but there are many indications that such responses occur in pregnancy (Payne and Rolfs, 1958; Hulka et al, 1963; Currie and Bagshawe, 1967; Van Rood, Eernisse, and Van Leeuwen, 1968; Loke, Joysey, and Borland, 1971).

What do not appear to have been published are accounts of work on such responses specifically in women where pregnancies were complicated by preeclamptic toxaemia. Again, it is to be hoped that ad hoc studies will be undertaken.

\section{REFERENCES}

Browne, F. J. and Sheumack, D. R. (1956). Chronic hypertension following pre-eclamptic toxaemia. The influence of familial hypertension in its causation. Fournal of Obstetrics and Gynaecology of the British Empire, 63, 677-679.

Chesley, L. C., Annitto, J. E., and Cosgrove, R. A. (1968). The familial factor in toxaemia of pregnancy. Obstetrics and Gynaecology, 32, 303-311.

Currie, G. A. and Bagshawe, K. D. (1967). Advances in Transplantation. Munksgaard, Copenhagen.

Davies, A. M. (1971). Geographical epidemiology of the toxaemias of pregnancy. Israel fournal of Medical Sciences, 7, 753-821.

Davies, A. M., Czaczkes, J. W., Sadowsky, E., Prywes, R., Weiskopf, P., and Sterk, V. V. (1970). Toxaemia of pregnancy in Jerusalem I. Epidemiological studies of a whole community. Israel fournal of Medical Sciences, 6, 253-266.

Einen, M. A. and Toppozada, H. K. (1966). Aspects of birth in the Shatby Hospital, Alexandria. British fournal of Preventive and Social Medicine, 20, 176-180.

Hamilton, M., Pickering, G. W., Roberts, J. A. F., and Sowry, G.S.C.(1954). The aetiology of essential hypertension. Clinical Science, 13, 11-35, 36-49, 267-271, and 273-304.

Hellman, L. M. and Pritchard, J. A. (1971). In William's Obstetrics, pp. 685-747. Butterworth, New York.

Hulka, J. F., Brinton, V., Schaaf, J., and Baney, C. (1963). Appearance of antibodies to trophoblast during the post partum period in normal human pregnancies. Nature, 198, 501-502.

Humphries, J. O. (1960). Occurrence of hypertensive toxaemia of pregnancy in mother-daughter pairs. Bulletin of the fohns Hopkins Hospital, 107, 271-277.

Jeffcoate, T.N. A. (1966). Pre-eclampsia and eclampsia: the disease of theories. Proceedings of the Royal Society of Medicine, 59, 397404.

Loke, Y. W., Joysey, U. C., and Borland, R. (1971). HL-A antigens and human trophoblastic cells. Nature, 232, 403-405.

Payne, R. and Rolfs, M. R. (1958). Anti-leucocyte antibodies in sera of multiparous women. Fournal of Clinical Investigation, 37, 1756.

Stevenson, A. C., Davison, B. C. C., Say, B., Ustuoplus, Liya D., Einen, M. A., and Toppozada, H. K. (1971). Contribution of fetal/maternal incompatability to aetiology of pre-eclamptic toxaemia. Lancet, 2, 1286-1289.

Stevenson, A. C., Johnston, H. A., Stewart, M. I. P., and Golding, D. R. (1966). Congenital malformations. A report of a study of series of consecutive births in 24 centres. Bulletin of the World Health Organization, 34, Suppl.

Van Rood, J. J., Eernisse, J. G., and Van Leeuwen, A. (1958). Anti leucocyte antibodies in sera of multiparous women. Nature, 181, $1735-1736$.

Zweifel, P. (1895). Zur Behandlung Der Eklampsie. Berichte Über 129 hier Beobachtete Fälle. Zentralblatt für Gynäkologie, 19, 1201-1218. 


\section{Appendix}

\section{CLASSIFICATION}

\section{(I) Acute toxaemia}

IA $\mathbf{A}_{1}=$ acute toxaemia (onset after 24 weeks) preeclamptic/mild:

(1) Blood pressure after 24 weeks $140 \mathrm{~mm} \mathrm{Hg}$ or more (systolic) or a rise of $30 \mathrm{~mm}$ or more above usual level, (diastolic) $90 \mathrm{~mm}$ or more or a rise of $15 \mathrm{~mm}$ or more above usual level.

(2) Proteinuria of significant degree.

(3) Persistent oedema of the hands or face.

$\mathbf{I A}=$ acute toxaemia (onset after 24 weeks) preeclamptic/severe:

(1) Blood-pressure $160 \mathrm{~mm} \mathrm{Hg}$ or more (systolic) or $110 \mathrm{~mm}$ or more (diastolic) on at least two occasions at intervals of $6 \mathrm{~h}$ with patient at bed rest.

(2) Proteinuria $5 \mathrm{~g}$ or more $(+++$ or ++++$)$.

(3) Oliguria ( $400 \mathrm{ml}$ or less in 24 hours).

(4) Cerebral or visual disturbances.

(5) Pulmonary oedema or cyanosis.
IB = Eclampsia (convulsions and/or coma when associated with hypertension, proteinuria, oedema).

\section{(II) Chronic hypertensive (vascular) disease associated with pregnancy}

IIA = Without superimposed acute toxaemia (no exacerbation of hypertension or development of toxaemia).

IIA $\mathbf{A}_{1}=$ Hypertension kncwn to have antedated pregnancy.

II $\mathbf{A}_{2}=$ Hypertension discovered in pregnancy (before 24 th week) and with post-partum persistence.

IIB $=$ With superimposed toxaemia.

III = Unclassified toxaemia (data insufficient to differentiate the diagnosis).

None $=$ No toxaemia . 